\title{
Kontribusi Sektor Pertanian terhadap Produk Domestik Regional Bruto (PDRB) di Kabupaten Tabalong
}

\section{(Agricultural Sector Contribution to Gross Regional Domestic Product (GRDP) in Tabalong Regency)}

\author{
Azwar Saihani*) \& Lina Heldayani \\ Program Studi Agribisnis Sekolah Tinggi Ilmu Pertanian Amuntai \\ ${ }^{*}$ Azwar.Saihani63@yahoo.com
}

\begin{abstract}
ABSTRAK
Penelitian ini bertujuan untuk mengetahui basis dan non basisnya, kontribusi serta pertumbuhan tiap subsektor pertanian terhadap PDRB di Kabupaten Tabalong dari tahun 2013 sampai 2017. Metode analisis yang dipakai yaitu analisis Location Quotient, kontribusi dan shift share. Data yang digunakan yaitu data PDRB Kabupaten Tabalong dari tahun 2013 sampai 2017 atas dasar harga konstan. Waktu penelitian dimulai dari bulan Maret 2018 sampai Juni 2019. Hasil penelitian berdasarkan analisis Location Quotient menunjukkan Subsektor yang menjadi subsektor basis adalah subsektor perkebunan sedangkan subsektor lainnya seperti tanaman pangan, holtikultura peternakan dan perikanan adalah subsektor nonbasis di Kabupaten Tabalong. Hasil analisis Kontribusi menunjukkan bahwa dari lima subsektor pertanian yang ada di Kabupaten Tabalong yang paling tinggi kontribusinya terhadap sektor pertanian adalah subsektor perkebunan dalam lima tahun terakhir sebesar 47,87\%. Hasil analisis Shift Share menunjukkan pertumbuhan tiap subsektor pertanian dalam perekonomian kabupaten Tabalong berbeda-beda dilihat dari pertumbuhan proporsionalnya subsektor tanaman pangan, peternakan, perikanan mengalami pertumbuhan yang cepat sedangkan subsektor holtikultura dan perkebunan mengalami pertumbuhan yang lambat, empat subsektor pertanian pertumbuhan wilayahnya kompetitif hanya subsektor perkebunan yang tidak kompetitif atau kurang bisa berdaya saing dengan wilayah lain yang ada di Provinsi Kalimantan Selatan.
\end{abstract}

Kata kunci: Kontribusi, subsektor, pertanian dan pertumbuhan.

\section{ABSTRACT}

This study aims to determine the basis and non-basis, the contribution and growth of each agricultural subsector to the GRDP in Tabalong Regency from 2013 to 2017. The analytical method used is the Location Quotient analysis, contributions, and shift-share. The data used are Tabalong Regency GRDP data from 2013 to 2017 based on constant prices. The time of the study starts from June 2018 until August 2019. The results of the study based on the Location Quotient analysis show that the subsector that is the base subsector is the plantation subsector while the other subsectors such as food crops, horticulture, and fisheries are the non-basis subsector in Tabalong Regency. The results of the Contribution analysis show that of the five agricultural subsectors in Tabalong District, the highest contribution to the agricultural sector was the plantation subsector in the last five years by $47.87 \%$. The results of the Shift Share analysis show the growth of each agricultural sub-sector in the economy of the Tabalong district is different as seen from the proportional growth of the food crops, livestock and fisheries sub-sectors experiencing rapid growth while the horticulture and plantation sub-sectors experienced slow growth. which is not competitive or less competitive with other regions in South Kalimantan Province.

Keywords: Contribution, sub-sector, agricultural and growth.

\section{PENDAHULUAN}

Sektor pertanian mendapat prioritas utama karena sektor ini ditinjau dari berbagai segi memang merupakan sektor dominan dalam ekonomi nasional. Misalnya kontribusinya dalam pendapatan nasional, peranannya dalam pemberian lapangan kerja pada penduduk yang bertambah dengan cepat, kontribusinya dalam menghasilkan devisa dan lain-lain (Rochaeni, 2014). 
Subsektor tanaman pangan terdiri dari komoditi bahan pangan, palawija dan holtikultura. Kabupaten Tabalong tidak bisa hanya mengandalkan pada satu jenis komoditi saja sebagai penyangga utama dalam perekonomiannya. Terkait dengan alasan tersebut maka yang perlu dilakukan oleh Pemerintah Daerah Kabupaten Tabalong adalah menyusun strategi pengembangan dari komoditi tanaman bahan pangan agar masyarakat dapat mempunyai komoditi lain yang dapat diunggulkan, khususnya pada komoditi tanaman bahan pangan karena bahan pangan merupakan kebutuhan pokok yang dikonsumsi setiap hari sehingga mempunyai prospek yang bagus untuk dikembangkan dan Pemerintah Daerah Kabupaten Tabalong mampu mempertahankan posisi komoditi bahan pangan sebagai komoditas unggulan. Sektor pertanian penting untuk terus dikembangkan dalam upaya meningkatkan pembangunan perekonomian wilayah Kabupaten Tabalong dengan memperhatikan potensi sumber daya alam dan sumber daya manusia yang dimiliki (BPS Tabalong, 2018).

Perkembangan pertanian dalam indikator ekonomi tidak hanya dapat dilihat dari Produk Domestik Bruto yang melihat pertumbuhan ekonomi negara saja, namun kita juga dapat melihat pertanian dari Produk Domestik Regional Bruto yang melihat pertumbuhan ekonomi wilayah seperti Provinsi atau Kabupaten/Kota. Semua provinsi di Indonesia berkontribusi dalam menyumbang Produk Domestik Regional Bruto untuk pertanian.

Kontribusi sektor pertanian terhadap Produk Domestik Regional Bruto (PDRB) Kabupaten Tabalong dari tahun 2013-2017 cenderung mengalami naik turun. Hal tersebut dikarenakan terdapat peningkatan di beberapa sektor lain seperti sektor pertambangan dan penggalian, industri pengolahan, jasa keuangan dan suransi serta sektor-sektor lainnya. Meskipun sektor lain mengalami peningkatan namun tidak mengubah posisi sektor pertanian sebagai posisi yang berada di peringkat kedua sebagai penyumbang perekonomian terbesar di Kabupaten Tabalong setelah sektor pertambangan dan penggalian. Kondisi ini mengidentifkasikan bahwa sektor pertanian adalah sektor yang sangat berpotensi dalam menyumbang PDRB dimana semakin tinggi tingkat pendapatan di sektor pertanian maka semakin tinggi pula tingkat laju pertumbuhan PDRB di Kabupaten Tabalong.

Oleh karena itu penelitian ini bertujuan untuk mengetahui subsektor pertanian apa yang basis dan nonbasis di Kabupaten Tabalong, seberapa besar kontribusi subsektor pertanian terhadap PDRB dan pertumbuhan subsektor pertanian di Kabupaten Tabalong.

\section{METODOLOGI PENELITIAN}

\section{Tempat dan Waktu Penelitian}

Penelitian ini dilaksanakan di Kabupaten Tabalong yang secara administratif terdiri dari 12 kecamatan, yaitu Kecamatan Banua Lawas, Pugaan, Kelua, Muara Harus, Tanta, Tanjung, Murung Pudak, Haruai, Bintang Ara, Upau, Muara Uya, dan Jaro. Penelitian ini dilaksanakan mulai dari bulan Maret 2018 sampai Juni 2019.

\section{Jenis dan Sumber Data}

Jenis data yang digunakan dalam penelitian ini adalah data sekunder. Data Sekunder adalah data yang diperoleh dari instansi atau lembaga yang berhubungan dengan penelitian ini. Dalam penelitian ini data yang diperoleh dari Badan Pusat Statistik (BPS) Kabupaten Tabalong, Badan Perencanaan dan Pembangunan Daerah (BAPPEDA) Kabupaten Tabalong dan instansi-instansi lainnya.

\section{Metode/Jenis Penelitian}

Metode pengumpulan data yang digunakan adalah metode dokumentasi yaitu metode yang mengumpulkan data dan hal-hal yang berupa catatan, transkrip, buku, surat kabar, majalah, notulen, raport, agenda dan sebagainya. Metode ini memilki beberapa kelebihan seperti hemat waktu, tidak perlu pengantar orang lain, tidak menimbulkan kecurigaan dan dapat mengetahui data yang berlalu (Arikunto, 2006).

\section{Analisis Data}


1. Identifikasi Sektor Pertanian Analisis Location Quotient (LQ) digunakan untuk mengidentifikasi sektor pertanian apakah menjadi sektor basis atau non basis di Kabupaten Tabalong. Besarnya nilai LQ dapat diperoleh dari persamaan sebagai berikut:

$$
\mathrm{LQ}=\frac{V i(s) / V(s)}{V i r / V r}
$$

Dimana:

LQ : Location Quotient

vi : Nilai PDRB sektor i di Kabupaten

Tabalong

vt : Total nilai PDRB di Kabupaten

Tabalong

Vi : Nilai PDRB sektor i Kalimantan Selatan

Vt : Total nilai PDRB Kalimantan Selatan.

Kriteria:

1) $L Q>1$ maka sektor pertanian dikategorikan basis, dan bisa di ekspor ke luar wilayah

2) $\mathrm{LQ}=1$ maka sektor pertanian dikategorikan tertutup, habis untuk konsumsi

3) $\mathrm{LQ}<1$ maka sektor pertanian dikategorikan non basis

2. Kontribusi Sektor Pertanian terhadap pembentukan total PDRB Kabupaten Tabalong. Dalam penelitian ini digunakan data PDRB ADHK tahun 2010. Dengan rumus yaitu:

Kontribusi $=\frac{\text { Nilai PDRB Sektor-i }}{\text { Total PDRB }} \times 100 \%$

3. Analisis Shift Share membandingkan perbedaan laju pertumbuhan berbagai sektor di daerah dengan wilayah nasional. Akan tetapi, metode ini lebih tajam dibandingkan dengan metode LQ. Metode LQ tidak memberikan penjelasan atas faktor penyebab perubahan sedangkan metode Shift Share memperinci penyebab perubahan atas beberapa variabel (Tarigan, 2018).

a). Komponen Pertumbuhan Regional (PR)

$$
\mathrm{PR}_{\mathrm{ij}}=(\mathrm{Ra}) \mathrm{Y}_{\mathrm{ij}}
$$

Keterangan:

$\mathrm{PR}_{\mathrm{ij}}$ : komponen pertumbuhan regional sektor i Kabupaten Tabalong
Ra : Rasio PDRB Kalimantan Selatan

$Y_{i j}$ : PDRB sektor i Kabupaten Tabalong pada tahun dasar analisis

b). Komponen Pertumbuhan Proporsional (PP)

Keterangan:

$$
\mathrm{PP}_{\mathrm{ij}}=(\mathrm{Ri}-\mathrm{Ra}) \mathrm{Y}_{\mathrm{ij}}
$$

$\mathrm{PP}_{\mathrm{ij}}$ : Komponen pertumbuhan proporsional sektor i Kabupaten Tabalong

Ri : Rasio PDRB sektor i Kalimantan Selatan

Ra : Rasio PDRB Kalimantan Selatan

$\mathrm{Y}_{\mathrm{ij}}$ : PDRB sektor I Kabupaten Tabalong pada tahun dasar analisis

Ketentuan setelah menghitung komponen PP, yaitu sebagai berikut:

a. Jika $\mathrm{PP}_{\mathrm{ij}}<0$ maka menunjukkan bahwa sektor i Kabupaten Tabalong laju pertumbuhannya lambat.

b. Jika $P P_{i j}>0$ maka menunjukkan bahwa sektor i Kabupaten Tabalong laju pertumbuhannya cepat.

c). Komponen Pertumbuhan Pangsa Wilayah (PPW)

$$
P P W_{i j}=(r i-R i) Y_{i j}
$$

Keterangan:

$\mathrm{PPW}_{\mathrm{ij}}$ : Komponen pertumbuhan pangsa wilayah sektor i Kabupaten Tabalong

ri : Rasio PDRB sektor i Kabupaten Tabalong

Ri : Rasio PDRB sektor i Kalimantan Selatan

$\mathrm{Y}_{\mathrm{ij}} \quad$ : PDRB sektor i Kabupaten Tabalong pada tahun dasar analisis

Kriteria:

a. Jika $P P W_{i j}>0$ maka sektor i pada wilayah Kabupaten Tabalong mempunyai daya saing yang tinggi dibandingkan dengan wilayah lainnya.

b. Jika PPW $\mathrm{ij}_{\mathrm{ij}}<0$ maka sektor i pada wilayah Kabupaten Tabalong mempunyai daya saing yang rendah dibandingkan dengan wilayah lainnya.

\section{HASIL DAN PEMBAHASAN}

\section{Hasil}

\section{Analisis LQ (Location Quotient)}

Tabel 1. Hasil Perhitungan Analisis LQ di Kabupaten Tabalong 


\begin{tabular}{cccccc}
\hline \multirow{2}{*}{ Tahun } & \multicolumn{5}{c}{ Lapangan Usaha } \\
\cline { 2 - 6 } & $\begin{array}{c}\text { Tanaman } \\
\text { Pangan }\end{array}$ & Holtikultura & Perkebunan & Peternakan & Perikanan \\
\hline 2013 & 0,85 & 0,32 & 1,67 & 0,65 & 0,39 \\
2014 & 0,85 & 0,35 & 1,65 & 0,17 & 0,39 \\
2015 & 0,86 & 0,40 & 1,63 & 0,74 & 0,43 \\
2016 & 0,91 & 0,43 & 1,58 & 0,76 & 0,46 \\
2017 & 0,95 & 0,43 & 1,56 & 0,76 & 0,46 \\
\hline Rata-rata & 0,88 & 0,39 & 1,62 & 0,62 & 0,43 \\
\hline
\end{tabular}

Keterangan Non Basis Non Basis Basis

Sumber: Hasil Pengolahan Data Sekunder, 2019.

\section{Analisis Kontribusi}

Tabel 2. Kontribusi Sektor Pertanian Terhadap Total PDRB Atas Dasar Harga Konstan Tahun 2013-2017.

\begin{tabular}{clccccc}
\hline \multirow{2}{*}{ No. } & \multirow{2}{*}{ Lapangan Usaha } & \multicolumn{5}{c}{ Kontribusi (\%) } \\
\cline { 3 - 6 } & 2013 & 2014 & 2015 & 2016 & 2017 \\
\hline \multirow{2}{*}{1} & Tanaman Pangan & 25,77 & 25,65 & 26,30 & 28,50 & 29,25 \\
2 & Hortilkultura & 0,33 & 0,35 & 0,40 & 0,44 & 0,43 \\
3 & Perkebunan & 54,77 & 54,74 & 52,36 & 48,97 & 47,87 \\
4 & Peternakan & 5,70 & 5,76 & 6,39 & 6,76 & 6,91 \\
5 & Perikanan & 8,81 & 8,75 & 9,59 & 10,40 & 10,76 \\
\hline
\end{tabular}

Sumber: Hasil Pengolahan Data Sekunder, 2019.

\section{Analisis Shift Share}

Tabel 3. Pertumbuhan Regional Subsektor Pertanian Kabupaten Tabalong tahun 2013-2017.

\begin{tabular}{lcc}
\hline \multicolumn{1}{c}{ Lapangan Usaha } & Prij & Prij (\%) \\
\hline Tanaman Pangan & $51.316,82$ & 16,42 \\
Holtikultura & 657,14 & 16,42 \\
Perkebunan & $109.065,67$ & 16,42 \\
Peternakan & $11.350,64$ & 16,42 \\
Perikanan & $17.543,70$ & 16,42 \\
\hline
\end{tabular}

Sumber: Hasil Pengolahan Data Sekunder, 2019.

Tabel 4. Pertumbuhan Proporsional (PP) Kabupaten Tabalong Tahun 2013-2017.

\begin{tabular}{lccc}
\hline \multicolumn{1}{c}{ Lapangan Usaha } & PPij & PPij $(\%)$ & $\begin{array}{c}\text { Keterangan } \\
\text { Pertumbuhan }\end{array}$ \\
\hline Tanaman Pangan & 5724,59 & 1,83 & Cepat \\
Holtikultura & $-77,79$ & $-1,94$ & Lambat \\
Perkebunan & $-47466,02$ & $-7,14$ & Lambat \\
Peternakan & 2902,78 & 4,20 & Cepat \\
Perikanan & 6857,39 & 6,42 & Cepat \\
\hline
\end{tabular}

Sumber: Hasil Pengolahan Data Sekunder, 2019.

Tabel 5. Pertumbuhan Pangsa Wilayah (PPW) Subsektor Pertanian Kabupaten Tabalong Tahun 2013-2017. 


\begin{tabular}{lccc}
\hline Lapangan Usaha & PPWij & PPWij $(\%)$ & Keterangan \\
\hline Tanaman Pangan & 45300,97 & 14,49 & Kompetitif \\
Holtikultura & 1517,59 & 37,91 & Kompetitif \\
Perkebunan & $-46886,16$ & $-7,06$ & Tidak Kompetitif \\
Peternakan & 14628,86 & 21,16 & Kompetitif \\
Perikanan & 21371,87 & 20,00 & Kompetitif \\
\hline
\end{tabular}

Sumber: Hasil Pengolahan Data Sekunder, 2019.

\section{Pembahasan}

\section{Analisis LQ (Location Quotient)}

Berdasarkan hasil analisis data menunjukkan bahwa nilai LQ tertinggi dimiliki oleh subsektor perkebunan yaitu 1,62 subsektor tersebut bernilai basis karena nilainya lebih dari satu. Sedangkan subsektor tanaman pangan yaitu 0,88 dan subsektor peternakan yaitu 0,62 subsektor perikanan 0,43 dan tanaman holtikultura 0,39 tidak basis karena nilainya kurang dari satu. Dengan demikian sektor pertanian, kehutanan dan perikanan di Kabupaten Tabalong belum mampu memenuhi kehutuhan lokal dan tidak dapat untuk melakukan kegiatan ekspor ke wilayah lain.

Menurut Tarigan (2018), jika nilai LQ>1 berarti peran sektor tersebut lebih menonjol dan jika LQ $<1$ berarti sektor tersebut merupakan sektor non basis. Sedangkan menurut Sjafrizal (1985), menyatakan bahwa sektor non basis adalah sektor-sektor yang memang kurang potensial dan tidak mempunyai keuntungan komptetitif tetapi berfungsi sebagai penunjang sektor basis atau service industries.

\section{Analisis Kontribusi}

Berdasarkan hasil penelitian dapat dilihat kontribusi setiap sub sektor pertanian terhadap total PDRB Kabupaten Tabalong menunjukkan bahwa dari kelima subsektor diatas subsektor perkebunan merupakan subsektor dengan persentase tertinggi dibandingkan dengan subsektorsubsektor lainnya dengan persentase sebesar 47,87 persen sedangkan sub sektor yang memiliki persentase terendah adalah sub sektor hortikultura dengan persentae sebesar 0,43 persen. Hal ini terjadi karena sub sektor hortikultura bukanlah sumber utama mata pencaharian masyarakat Kabupaten Tabalong. Sehingga persentase sub sektor hortikultura dari tahun ke tahun selalu lebih rendah dari persentase sub sektor-sub sektor lainnya. Hasil penelitian Risnawati (2016) di Kabupaten Jeneponto menunjukkan bahwa sub sektor tanaman pangan merupakan subsektor yang memiliki kontribusi tertinggi yaitu sebesar 78,62 persen dan subsektor kehutanan adalah sub sektor yang memilki kontribusi terendah sebesar 0,05 persen. Ini pun berhubungan dan sesuai dengan pendapatnya Halim (2010) bahwa besar kecilnya kontribusi yang dapat disumbangkan dan outputnya setiap sub sektor pertanian sangat mempengaruhi peranan dalam perekonomian di tiap kabupaten dan mampu meningkatkan kesejahteraan masyarakat terutama masyarakat yang dominannya bekerja sebagai petani.

\section{Analisis Shift Share}

Berdasarkan Tabel 3 dapat dilihat bahwa pertumbuhan sub sektor pertanian di Kabupaten Tabalong dipengaruhi secara positif oleh pertumbuhan perekonomian Provinsi Kalimantan Selatan. Sub sektor pertanian Kabupaten Tabalong yang mendapat pengaruh paling besar dari pertumbuhan perekonomian Provinsi Kalimantan Selatan adalah sub sektor perkebunan diikuti sub sektor tanaman pangan, sub sektor perikanan, sub sektor peternakan dan yang terkecil mendapat pengaruh dari pertumbuhan perekonomian Provinsi Kalimantan Selatan adalah sub sektor holtikultura.

Berdasarkan Tabel 4 dapat dilihat bahwa ada tiga sub sektor dalam sektor pertanian di Kabupaten Tabalong yang memiliki nilai pertumbuhan proporsional 
positif. Dimulai dari yang memiliki nilai (PP) terbesar yaitu sub sektor perikanan, kemudian sub sektor peternakan dan sub sektor tanaman pangan. Ketiga sub sektor ini memiliki nilai pertumbuhan proporsional sub sektor positif $(\mathrm{PPij}>0)$ yang artinya ketiga sub sektor ini memiliki tingkat pertumbuhan yang cepat. Kemudian dua sub sektor pertanian yang tersisa mendapat nilai pertumbuhan proporsional negatif, yaitu sub sektor perkebunan dan sub sektor holtikultura. Kedua sub sektor pertanian ini mendapatkan nilai pertumbuhan proporsional sub sektor pertanian negatif $(\mathrm{PPij}<0)$ yang berarti tingkat pertumbuhan kedua sub sektor ini lambat.

Berdasarkan Tabel 5 dapat dilihat bahwa sub sektor dalam sektor pertanian Kabupaten Tabalong memiliki nilai positif yaitu sub sektor holtikultura, sub sektor peternakan, sub sektor perikanan, dan sub sektor tanaman pangan dan sub sektor yang memiliki nilai negative yaitu perkebunan. Nilai pertumbuhan pangsa wilayah negatif artinya sub sektor tersebut memiliki daya saing yang kurang baik terhadap sub sektor dalam sektor pertanian di wilayah lain (Kabupaten/Kota) di Provinsi Kalimantan Selatan (Tidak Kompetitif), sedangkan nilai positif artinya sub sektor tersebut memiliki daya saing yang baik terhadap sub sektor di wilayah (Kabupaten/Kota) lain di Provinsi Kalimantan Selatan. Menurut Sudarsono (2001) peneyebab suatu komoditas kompetitif dan tidak kompotetif dilihat dari sisi skill (dengan kriteria-kriteria tingkat pendidikan, tingkat pelatihan, pengalaman kerja, jumlah pelatihan) dan faktor lainnya seperti bahan baku, modal, saran produksi/usaha, teknologi, dukungan sosial budaya, manajamen, pasar, harga dan peran dalam ekonomi.

\section{KESIMPULAN}

Subsektor yang menjadi subsektor basis dalam perekonomian Kabupaten Tabalong, yaitu subsektor perkebunan. Sedangkan subsektor tanaman pangan, holtikulturan, peternakan dan subsektor perikanan adalah subsektor non basis dalam perekonomian Kabupaten Tabalong. Kontribusi tiap sub sektor pertanian dari tahun 2013-2017 cenderung mengalami fluktuatif (cenderung turun naik). Subsektor yang mengalami pertumbuhan yang cepat atau yang mendapat nilai positif berdasar komponen pertumbuhan proporsional $(\mathrm{Pp})$ yaitu subsektor perikanan, subsektor peternakan dan subsektor tanaman pangan. Dan subsektor yang mengalami pertumbuhan lambat dibandingkan pertumbuhan ditingkat Provinsi Kalimantan Selatan yaitu subsektor perkebunan dan subsektor hortikultura. Semua subsektor pertanian di Kabupaten Tabalong baik itu subsektor tanaman pangan, holtikultura, peternakan dan perikanan mengalami pertumbuhan wilayah $(\mathrm{Pw})$ yang baik atau kompetitif jika dibandingkan dengan wilayah-wilayah lain di Provinsi Kalimantan Selatan. Hanya subsektor perkebunan yang mengalami pertumbuhan wilayah $(\mathrm{Pw})$ yang kurang baik atau tidak kompetitif jika dibandingkan dengan wilayah-wilayah lain di Provinsi Kalimantan Selatan. Sehingga pemerintah harus lebih memperhatikan tiap subsektor pertanian untuk dikembangkan sehingga menjadi subsektor yang kompetitif.

\section{DAFTAR PUSTAKA}

Arikunto, S. (2006). Prosedur Penelitian Suatu Pendekatan Praktik. Eka Cipta. Jakarta.

BPS Tabalong. (2018). Tabalong Dalam Angka 2017. Tanjung.

BPS Kalimantan Selatan. (2018). Kalimantan Selatan Dalam Angka 2017. Banjarmasin.

Halim, A. (2010). Dasar-dasar Akuntansi Biaya. Edisi 4. BPFE. Yogyakarta.

Risnawati. (2016). Kontribusi Sektor Pertanian Terhadap Produk Domestik Regional Bruto (PDRB) Kabupaten Jeneponto. Skripsi. Universitas Islam Negeri Alauddin Makassar. (repository.uin- 
Azwar Saihani \& Lina Heldayani, Kontribusi sektor pertanian terhadap produk..

alauddin.ac.id, Di akses pada tanggal 3 Januari 2019).

Rochaeni, S. (2014). Pembangunan Pertanian Indonesia Edisi 2. Graha Ilmu. Yogyakarta.

Sudarsono, R.M. (2001). Upah Minimum, Upah Sektoral, dan Produktivitas Sektor Industri di Indonesia. Yogjakarta.

Suyatno, S. (2007). Analisa Economic Base Terhadap Pertumbuhan Ekonomi
Daerah Tingkat II Wonogiri : Menghadapiimplementasi UU No. 22/1999 dan UU No. 5/1999. Jurnal Ekonomi Pembangunan: Kajian Masalah Ekonomi dan Pembangunan, 1(2), 144-159. doi:https://doi.org/10.23917/jep.v1i 2.3899 .

Tarigan, R. (2018). Ekonomi Regional Teori dan Aplikasi. PT Bumi Aksara. Jakarta. 